\title{
Invasions of four South American tramp ants: a systematic review
}

\section{Invasiones de cuatro hormigas vagabundas suramericanas: una revisión sistemática}

\author{
Ingeborg Zenner de Polanía
}

${ }^{1}$ Ing. Agrónoma, Ph.D. Universidad de Ciencias Aplicadas y Ambientales U.D.C.A, Calle 222 No. 55-37, Bogotá, D.C., Colombia, e-mail: izenner@udca.edu. co, (Dhttps://orcid.org/0000-0002-7820-7138

Cómo citar: Zenner de Polanía, I. 2019. Invasions of four South American tramp ants: a systematic review. Rev. U.D.C.A Act. \& Div. Cient. 22(1):e1207. https://doi.org/10.31910/rudca.v22.n1.2019.1207

Artículo de acceso abierto publicado por Revista U.D.C.A Actualidad \& Divulgación Científica bajo una licencia Creative Commons CC BY-NC 4.0

Recibido: Enero 13 de 2019

Aceptado: Mayo 16 de 2019

\begin{abstract}
The invasion and spread of four native South American ants (Hymenoptera: Formicidae) Linepithema bumile, Solenopsis invicta, Wasmannia auropunctata and Paratrechina (Nylanderia) fulva all over the world, their environmental and economic impact, and intended control tactics are documented. Displacement of these invasive species is triggered by human international movement of goods, and in one case, $P$. fulva, a deliberately introduction as a candidate for biological control of Atta spp. and snakes. These tramp ants displace native ants, attack native birds and reptiles, protect and transport sap sucking insects, cause damage to human commodities, and are able to cause health problems to men and domestic animals. Chemical control, producing negative environmental side effects, has shown poor success and short residual effect. Current tendencies use biological control agents, the natural enemies, parasites, predators and diseases of their original range. Quarantine and eradication programs have been implemented. The success of the tramp ants involves a small size that permits hiding in all types of packing materials, their organization in societies, varied diets, and in many cases to their late detection and initial control.
\end{abstract}

Keywords: invasion biology; insect invaders; exotic species; Formicidae; pests.

\section{RESUMEN}

La invasión y la diseminación en todo el mundo, de cuatro hormigas sudamericanas nativas (Hymenoptera: Formicidae) Linepithema bumile, Solenopsis invicta, Wasmannia auropunctata y Paratrechina (Nylanderia) fulva, su impacto ambiental y económico y las medidas de control empleadas, es documentado. El desplazamiento involuntario, se desencadena por el transporte internacional de bienes por los humanos y, en un caso, $P$. fulva, incluso, se introdujo deliberadamente, como posible agente de control biológico de Atta spp. y culebras. Estas hormigas vagabundas desplazan, principalmente, a las hormigas nativas, atacan a algunos vertebrados, aves, reptiles, entre otros, protegen y transportan insectos chupadores, dañan los productos humanos y pueden causar problemas de salud a hombres y animales domésticos. El control químico, además de sus efectos secundarios negativos ambientalmente, ha tenido poco éxito y un efecto residual corto y la tendencia actual es el uso de agentes de control biológico, teniendo en cuenta, que las hormigas traídas a su nuevo ecosistema han dejado atrás a sus enemigos naturales, parásitos, depredadores y enfermedades. También, para evitar nuevas invasiones o nuevas infestaciones, se han implementado medidas especiales de cuarentena y programas de erradicación. El éxito de las hormigas vagabundas, se debe, en parte, a su pequeño tamaño, que permite que se escondan en todo tipo de productos utilizados como material de embalaje, para el movimiento de productos, a su 
organización social, a sus variados hábitos alimentarios y, en muchos casos, hasta a su detección tardía.

Palabras clave: biología de la invasión; invasores insectiles; especies exóticas; Formicidae; plagas.

\section{INTRODUCTION}

Among the invasive insect species, the most destructive ones are considered to be the ants (Van Wilgenburg et al. 2010) and among them those of South American origin, which have been introduced accidentally or deliberately to other continents or other latitudes. The increase of commercial activities since the beginning of the XX century has facilitate the transport of many not desirable invaders, such as weeds, arthropods, diseases, to name only few groups (Forel, 1911). Many inclusions of small insects, such as ants in the luggage of passengers, mainly with seeds and stakes, were introduced undetected. The original migration of tramp ants has however not been documented and can only be imagined.

During the $1^{\text {rst }}$ International Congress of Entomology in 1910, in Brussels, Forel (1911) mentioned 11 cosmopolitan ant species, distributed by human activities and established in new environments, including the genera Soleopsis, Pheidole, Iridomyrmex and Cardiocondyla, all of them today considered tramp ants.

Tramp ants are defined by Hölldober \& Wilson (1990) as formicids that are distributed around the world, mainly through human commercial activities and live in close connection with men. These authors mention as notorious tramp species the pharaoh ant, Monomorium pharaonis (Linnaeus, 1758) (Myrmicinae), the big-headed ant, Pheidole megacephala (Fabrricius, 1793) (Myrmcinae), the Argentine Ant, Iridomyrmex bumilis, sinónimo de Linepithema bumile (Mayr, 1868) (Dolichoderinae) and the little fire ant, Wasmannia auropunctata (Roger, 1863) (Myrmicinae). Passera (1994) added, among others, the pavement ant, Tetramorium caespitum (Linnaeus, 1758) (Myrmicinae), a crazy ant, Paratrecbina longicornis (Latreille, 1802) (Formicinae) and two species of the genus Cardiocondyla (Myrmicinae). For the purpose of this study, the crazy ant, Paratrechina (Nylanderia) fulva (Mayr, 1862) (Formicinae) and the red imported fire ant Solenopsis invicta Buren, 1972 (Myrmicinae) are included.

Invasion biology, a relatively "new" scientific discipline, which has gained special importance, focusses and has as main research objectives all the relevant aspects related with the migration and transport of living entities from its original habitat to other places, with the consequent impact on the existing biodiversity (Kegel, 2001). As part of this discipline as special study objective it includes the tramp ants, cosmopolitans and generalists, which normally prefer disturbed habitats, and live in close proximity with humans. Kegel (2001) cites as the most important tramp ants $W$. auropunctata, $L$. bumile, M. pharaonis, Ph. megacephala, Anoplolepis longipes and Tapinoma melanocephalum.

The importance of this branch of the biology is also reflected in the creation, since March 1999, in a series of publications, the journal Biological Invasions, publishing monthly research and synthesis papers on patterns and processes of biological invasions in terrestrial, freshwater, and marine (including brackish) ecosystems, also includes conservation programs, global enhancement and management of invasions.

This review documents the invasive behavior, through time, of four South American tramp ants, which actually are present in North America, Central America, Galapagos Island, Australia, New Zealand, Africa, Oceania, Europe, China, Japan, among other conquered regions, causing economic and environmental damage and are considered pests.

\section{MATERIALS AND METHODS}

For this systematic review, four recognized treaties which the main component "myrmecology", we reviewed Hölldober \& Wilson's (1990) The ants; Exotic Ants Biology, Impact, and Control of Introduced species, edited by D.E. Williams (1994); Vander Meer et al. (1990). Applied Myrmecology. A World Perspective and "Die Ameise als Tramp", Kegel (2001). Additionally, publications of the Entomological Society of America, SciELO - Scientific electronic library online, the "Revista Colombiana de Entomología" y other Colombian journals, using the terms: Linepithema humile, Wasmannia auropunctata, Paratrechina (Nylanderia) fulva and Solenopsis invicta, alone or combined with words such as, biology, invasion, impact, control.

\section{RESULTS AND DISCUSSION}

Origin, migration, internal movement: Both $L$. bumile and $S$. invicta are considered native to Argentina; the imported fire ants also from Mato Grosso, Brazil (Buren, 1972). The first one, believed to be the world most successful invasive species, with its native range around the Paraná River Drainge, (Wild, 2004), seems to have reached the United States in coffee shipments from Brazil to New Orleans around 1891 (Titus, 1905). Since its invasion in the United States, it has conquered the Carolinas and Southern Florida and has reached Texas and California (Wetterer et al. 2009). Suarez et al. (2001) define as poor its dispersal ability and attribute its worldwide movement to human-mediated diffusion.

Linepithema bumile has established in the North Carolina, but has not invaded regions farther north. Brightwell et al. (2010) found that the foraging activity of the workers stops below $5^{\circ} \mathrm{C}$ and concluded that winter soil temperatures could impede foraging long enough to cause colony death. Although climatic changes are occurring all over the world, it can be assumed that in the near future the ant, were it has established in temperate zones, would not spread farther north.

The Argentine ant has been established on six continents and on many oceanic islands. Men-mediated jump dispersal has also been the primary means of distribution at a continental scale within the United States, South America, and New Zealand (Suarez et al. 2001).

In South and Central America, the Argentine ant occupies temperate and tropical regions, but apparently not as a dominant species 
(Wetterer et al. 2009). From Colombia there is only one documented record, specimens collected by William P. MacKay (North American myrmecologist entomologist who visited the country and at this time studied mainly the Atta spp.), in 1973, at Armenia (Quindio) and deposited in his private collection (Wetterer et al. 2009). In Mexico, it has been recorded in the states of México, Chiapas, Qintana Roo, between others and in San Luis Potosi (Rocha-Flores et al. 2018; Castaño-Meneses, 2012; Longino \& Fernández, 2007; Wild, 2004; Krauss, 1966).

In Australia, L. bumile was first detected in 1941 in Albany, Western Australia (Clark,1941) and rapidly invaded southwestern regions, including the Perth urban area (Van Schlagen et al. 1994). The same authors mention that the ant has occupied almost all major cities in southwestern Western Australia and that by 1991, the infested area was estimated to be 2932 hectares. The spread of L. bumile is due to humans by means of transport of many commodities, mainly soil and potted plants, since nurseries within in the metropolitan area of Perth are infested and present a serious risk of distribution to areas free of the tramp ant (Van Schlagen et al. 1994).

One of the most recent detections of the Argentine ant has been documented by Green, in Auckland, New Zealand, in 1990. This tramp ant is found mainly in urban environments of northern parts of New Zealand, spreading to new sites, not by natural means, but by human influenced dispersal (Ward et al. 2005). A very complete review of the L. bumile's invasion biology is given by Ward et al. (2010), with emphasis on its "potential distribution, dispersal patterns, detection, impacts, and Control" in New Zealand. Regarding the invasion of the Argentine ant in New Zealand, Harris \& Barker (2007) assume that taking into account the cooler climate of the island, the problems caused will not be as severe as reported in warmer climates around the world; inclusively it is possible the ant won't become established in many sites where it will be accidently introduced. Their assumption contradicts, Gómez et al. (2005), who detected $L$. bumile in a building time in Norway, mentioning that this is, at the moment, the most northern invasion report. Wild (2004) recorded an infestation in Edinburgh, United Kingdom, being this the first official record of the ant in the old world. The presence in Norway of $L$. bumile is a well-documented human mediated "import". The persons living in the infested apartment had brought the ant from Italy and Spain with their horses; the ants were also detected in the trailer in which the horses were transported (Gómez et al. 2005).

There are many more records of the presence of $L$. bumile in locations with colder climates than those of tropical or subtropical regions. However, these reports of invading Argentine ants come from populations found indoors. Interesting observations were made in 2004, by Roura-Pascual et al. (2004), who forecasted the potential geographical invasions of the Argentine ant, based on the global warming due to the climate change; the areas which will be more vulnerable for the invasions and possible establishment are the higher latitude sites.
Similar routes of dispersion around the word have been documented for the red imported fire ant Solenopsis invicta Buren, judged to be one of the most important ant tramp species. Native to South America, Mato Grosso, Brazil (Williams et al. 1975), Uruguay and Argentina it has invaded the United States (Callcott \& Collins, 1996), Mainland China, Taiwan, Australia, Mexico (Sánchez Peña et al. 2009) and the Caribbean (Wetterer et al. 2014; Wetterer \& Davis, 2010; Wetterer \& Snelling 2006; Davis et al. 2001; Lofgren,1986) and recently the news (NHK channel) has reported several detections, in Japan.

According to Davis et al. (2001), S. invicta widespread in the West Indies, apparently is still not present in Jamaica, Hispaniola, and Cuba. Its absence in Cuba is mentioned in 2011, by Fontenla Rizo \& Matienzo Brito.

The date of introduction of the red imported fire ant into the United States is placed sometimes between 1933 and 1945, at Mobile, AL., coming possibly in ships' ballast from Brazil. Solenopsis invicta has occupied a wide range in the southern United States and already by 1985 it had been detected in over 9.3 million $\mathrm{km}^{2}$ (USDAAPHIS, Gov., 2018; Jemal \& Hugh-Jones, 1993).

In contrast to $L$. bumile, ant up to now apparently not detected in China, S. invicta has been mentioned in China, since 2003, identification confirmed by mitochondrial DNA and assumedly introduced from the United States (Zhang \& Hou, 2013). Zhang et al. (2007) mention its presence in Taiwan in 2003 and indicate that in South China it has rapidly invaded many provinces such as Guangdong, Guangxi, Hunan, Fujian and Jiangxi. In Mainland China, Zeng et al. (2005) date its introduction to 2004. In 2012, S. invicta has been reported from five provinces in South China and is considered to have the capacity to invade regions further north, by means of both natural dispersal and human transportation; it has been found that its population increases greatly in spring and autumn (Wang et al. 2012).

The Argentine ant is registered in Europe, while according to Ascunce et al. (2011), the red imported fire ant has not yet invaded this continent. An exhaustive literature review confirms this. Solenopsis invicta has been detected in various commodities imported from the United States, however it has not been established, or invaded Spain, Italy, or other Mediterranean countries.

In Australia $S$. imvicta is considered the worst invasive ant species to arrive at the eastern shores, contrary to $L$. bumile which started the invasion at the western regions of the continent. This contrasting arrival can be attributed to the importance of the east coast ports for imports of goods. Solenopsis invicta was first reported in 2001, at the Port of Brisbane and in some south western suburbs of this city (Moloney \& Vanderwoude, 2002). Additional invasions were discovered in the following years, 2006, 2013, 2015 and the Port of Brisbane, in 2016. Red imported fire ants were detected at the Port Botany, Sydney in 2014 (National pest \& disease outbreaks, 2018; Wylie \& Janssen-May, 2016).

Up to 2009 three different invasions of the red fire ant have been reported in New Zealand; the first two occurred in 2001, at 
Auckland Airport and the second at Port of Napier, 2004, both successfully managed and eradicated. At that moment north of Napier, an eradication program was undertaken, (Ward, 2009). Apparently, no new invasions to New Zealand occurred during the following years, due to strict airport measurements and detection procedures.

The most recent report of an invasion by Solenopsis invicta comes as news report from Japan, where the Red Imported fire ant was discovered in 2017, in shipping containers coming from China; consequently, Japan's Ministry of Transportation ordered detection and extermination measures at more than 60 ports with regular cargo shipments from China (Globalvoices Org, 2017).

The third tramp ant, the little fire ant, Wasmannia auropunctata, possibly would not have gained so much attention and research, if it had not been brought accidentally to the Galapagos Islands. Foucaud et al. (2010) mention that it is still one of the least studied invasive species. Lubin (1984) documented the invasion in five islands in the Galápagos archipelago and De La Vega (1994) mentions its probable introduction between 1930 and 1940, while Brandão \& Paiva (1994) analyzed the Galapagos ant fauna, with emphasis on the little fire ant and other introduced ant species.

Native to the tropics and subtropics of America, W. auropunctata shows a distribution range from central Argentina and Uruguay, through eastern Mexico, to the southernmost area of Texas (Wetterer, 2013; Kusnekov, 1951). Invasions to Europe, Africa, Australia, Oceana and the West Indies are well documented (Wetterer, 2013; Foucaud et al. 2010; Jucker et al. 2008; Walsh et al. 2004; Wetterer $\&$ Porter, 2003). Special attention is given to several introductions, for example to Israel where its establishment has recently been recorded raising alarm about potential further distribution to the Mediterranean region (Vonshak et al. 2010).

The ant's ecology and interaction with other native ants has been studied in Colombia (Salguero et al. 2011; Achury et al. 2008; Armbrecht et al. 2001). Observations in the department of Cundinamarca indicate that it is very common in the coffee growing area, from 1000 to 1550 m.a.s.l., and feared for its painful sting by coffee pickers. Tennant (1994) studied its ecology in a tropical rainforest of Costa Rica and Panama and Delabie et al. (1994) documented the serious problems the ant causes in Brazilian's cocoa plantations for its symbiosis with homopterans and the painful sting they inflict to pod pickers.

Ulloa-Chacón \& Cherix (1990) highlight the following characteristics that allow $W$. auropunctata to become an effective invader: "its adaptability to a wide range of habitats; polyphagous feeding habits; high interspecific aggression; and lack of intraspecific aggression which leads to unicoloniality".

Of the four tramp ants, only Paratrechina (Nylanderia) fulva has been deliberately introduced, at least into Colombia, for biological control purposes. This ant has been recorded from Brazil, where it is a house pest, and a control agent of snakes and leaf cutting ants (Atta spp.), controlling efficiently the ant colonies (Mariconi, 1970; SoaresBrandão, 1941). These observations triggered several confirmed importations to Colombia during 1960s into the coffee growing area of the department of Cundinamarca, in 1971 to grassland of Puerto Boyacá, and in 1985 to sawmills in the region of CarareOpón (Santander), always for the purpose of either control Atta spp., or poisonous snakes (Zenner de Polanía, 1990a; 1990b; 1994). In 1986, the ant was detected in a sugarcane plantation in the Cauca Valley, presumably "imported" due to the rumor of its control of the sugarcane borer Diatraea sacacharalis, from where it spread to the "Reserva Natural Laguna de Sonso", causing a serious ecological impact (Aldana et al. 1995). Paratrecbina (Nylanderia) fulva was also introduced by farmers to the unrefined brown sugar production area of Barbosa (Santander), for the control of the sugarcane borer; in 1999, large areas of sugarcane plantations had been invaded, causing crop loss, mainly because of its association with the scale insect Pulvinaria pos. elongata (Zenner de Polanía et al. 2001).

Wetterer et al. (2014) recognizes the crazy ant as Nylanderia fulva Mayr, formerly Paratrechina fulva; in this review P. fulva is the accepted scientific name and used as such.

Paratrechina fulva is not only known and has been studied in Brazil and Colombia, but recently also in the United States, where it was reported already in1983 from Brownsville, Texas (Trager, 1984). According to LeBrun et al. (2013), this ecologically dominant and exotic ant species is spreading through the Southeastern United States and Texas. This ant is able to displace Solenopsis invicta. Paratrechina fulva is also reported from St. Croix, the U.S. Virgin Islands, suggesting an on-going population explosion (Wetterer $e t$ al. 2014). Fontenla Rizo \& Matienzo Brito (2011) as well as Fontenla et al. (1995) registered the presence of P. fulva, in Cuba.

This tramp ant has not crossed the border of South and North America, or to invade other continents, but taking into account the trade relations of the United States, Brazil and Colombia with Mainland China, Australia, Mediterranean regions of Europe and Africa, it is suggested to put Paratrechina (Nylanderia) fulva on the list of exotic tramp ants, since it represents high risks to native vertebrate species, due also to its protections and transport of homopterans, causing damage to human commodities, and is able to cause health problems to men and domestic animals. Strict port inspection measurements, quarantine and detection procedures should be implemented in all regions not invaded by the crazy ant.

Impact: The negative impact of the four tramp ants such as displacement of other ants; symbiosis with homopteran pests protecting and transporting mainly inmatures; the raid of native vertebrate species such as birds and reptiles; the damage to human commodities and health problems to men and domestic animals, has been well documented. Here some of the most prominent research will be presented and discussed.

In 1971, Erickson documented the displacement of three harvester ant species in California by the Argentine ant, indicated three competitive advantages of $I$. bumilis over the displaced native 
ants: "its aggressive nature; the large number of queens and the establishment of new colonies in a very short time; raiding columns of workers clear the way and pioneer groups of workers and queens follow into freshly opened nest areas.

Ward (1987) indicated that the species richness of native ants is markedly reduced in the lower Sacramento Valley of California at riparian woodland sites occupied by the Argentine ant. Apparently, the native epigaeic ants, aboveground foraging species are more susceptible to displacement than hypogaeic species.

During an invasion by the Argentine ant in northern California, its occurrence meant a disassembly of the native ant populations. Without $L$. bumile, native ant communities exhibit significant species segregation, while in the presence of the Argentine ant, they act randomly or weakly-aggregated (Sanders et al. 2003).

Similar results had been obtained by Porter \& Savignano (1990), studying over several years a $S$. invicta invasion in Texas. The red fire ant produced mayor changes in the abundance and diversity of other ant communities, reducing the native species richness, which declined by $70 \%$.

In Mainland China, native ant abundance was clearly reduced by $S$. invicta invasion, and the richness of ant species was reduced up to $46 \%$. The influence of $S$. invicta was found to be greatest within $5 \mathrm{~m}$ of its mound (Wang et al. 2012).

Wetterer \& Porter (2003), in their review of the distribution, impact and control of $W$. auropunctata, mention its relevant invasion in the Galapagos, causing the disappearance of native ants, and terrestrial invertebrates. According to Clark et al. (1982), the little fire ant, either eliminates or lessens, to very low numbers all sympatric ant species, while Lubin (1984) detected that the presence of $W$. auropunctata not only originated lower diversity and density of other ants, but also decreased densities of other insects, as well as scorpions and spiders.

The impact of Paratrechina fulva on other ant species has been studied, mainly in Colombia. Zenner de Polanía (1994) documented the displacement of at least fourteen ant species, when comparing three areas: invaded by the crazy ant, free of the invader; and one at the border of the infestation. The species diversity index of 0.763318 in the P. fulva free area dropped to 0.008795 in the completely P. fulva-infested area. Zenner de Polanía \& Ruiz Bolaños (1985) determined that the diet of $P$. fulva is constituted by a liquid component, obtained from sugary substances secreted by the sap sucking Homoptera, which in turn affect all types of vegetation, and another solid one, protein, from its predatory activity on some insects, arachnids and other animals, among them birds and reptiles. This ant has been found associated with 28 species of Homoptera, of 7 families (Zenner de Polanía \& Ruiz Bolaños, 1985). In Cuba, the crazy ant at high densities is capable of causing serious problems to chicken and pig production, as well as in apiaries (Fontenla et al. 1995). The association of $P$. fulva with the cottony grass scale Pulvinaria pos. elongata is another example of the negative impact of the deliberately introduced ant (Zenner de Polanía et al. 2001). In the Cauca Valley, the colonization of the crazy ant of the Laguna de Sonso Natural Reserve, has caused an important ecological impact. Comparing the ant fauna between an area free of the invader and one with a high population of $P$. fulva registered a reduction in ant species richness by $74 \%$ (Aldana et al. 1995). Even in its country of origin, Brazil, Campos-Farinha \& Zorzenon (2005) observed P. fulva interacting with the aphid Cerataphis brasiliensis and pseudococcids, transporting first instars nymphs from infested to uninfested palm plants.

In the U.S., P. fulva at high density has been found to eliminate $S$. invicta reducing also the abundance and species richness of other ants (LeBrun et al. 2013).

Not only the crazy ant uses honeydew produced by phloem-sucking hemipterans, considered a common behavior of many ant species. Mutualism is a wide spread and relevant ecological phenomenon illustrated by beneficial interaction between two species, ants and homopterans. In China, S. invicta has a close symbiosis with another introduced pest: Phenacoccus solenopsis. Defending the mealybug against its natural enemies, and significantly decreasing the survival of lady beetle larvae (Zhou et al. 2013).

Control, eradication: Toxic baits, chemical control and the use of biological control agents are the tools used to mitigate ant invasions, avoid their spread, and occasionally eradicate incipient arrivals. Whatever program is implemented for control purposes still further research is needed in order to produce an integrated management package.

However, prevention is the most effective instrument, to avoid the use of chemical control measurements, which will always affect negatively other non-target species. Therefore, an adequate and timely effective detection schedule in all ports of commodities entrance of the countries were tramp ants have not been introduced, is imperative. Training of the personal in charge of sanitary inspections in ant identification has to be procured, together with the correct information of world ant dispersal and the origin of the imported product and its package.

Equally public education, explaining and forewarning the general danger of introducing whatever biological element, specially ants as pets is fundamental.

Also, agricultural and food commodities shipped to markets abroad have to meet the importing countries' entry requirements, related to sanitary aspects, such as being free of pests, being this condition already the law in many countries around the world.

The most promising management measures of the tramp ants seem to be the use of parasites; being the classical biological control the most appropriate one. Survey of natural enemies in the sites of origin, extensive studies, mass rearing and supervised liberations is imperative. However, a complete control can never be guaranteed. Biological control will only be part of a management program. 
In the U.S. Phorid flies have been the main study target for biocontrol of Solenopsis invicta (Porter et al. 2003). Lately several of Pseudacteon spp. (Diptera: Phoridae) have been released throughout the southern United States; a decrease in its foraging intensity is expected having as result a decreased colony success (Puckett \& Harris, 2010), but not a complete control.

Caenocholax fenyesi (Strepsiptera: Myrmecolacidae), is known as a Texas native endoparasite of males of $S$. invicta and found in regions invaded by the ant (Cook et al. 1997). It seems to have adapted to the imported host, however, apparently, no intend of using it as biological control agent have been made.

Another biological control approach is the incorporation of entomopathogenic fungi, such as Beauveria bassiana into baits. $B$. bassiana alginate pellets, coated with peanut oil produced significant decrease in $S$. invicta population indices and could be recommended as control measurement in the field (Bextine \& Thorvilson, 2002). A survey of the presence of key pathogens and parasites of S. invicta in the West Indies, undertaken by Valles et al. (2015), revealed as the most promising pathogen the microsporidian Kneallhazia solenopsa; also, Vairimorpha invictae, was detected in St. Croix, as well as the Solenopsis invicta densovirus (SiDNV). Two species of Pseudacteon decapitating flies were found to have dispersed into the Bahamas. The authors discuss these islands "for release, establishment, and impact assessment of S. invicta natural enemies."

Eradication programs of Solenopsis invicta have been implemented mainly in New Zealand and Australia. Wylie \& Janssen-May (2016) mentioned several successful eradications of the insect has since 2001, when the red fire ant was first reported in Brisbane, Queensland. However, the main Brisbane population remains. The authors insist in an eradication program since it "remains technically feasible, cost beneficial and in the national interest to eradicate". Actually, Australia has given up on this effort. A successful eradication of the red imported fire ant has been reported for northern Taiwan, using pyriproxyfen; after one year, S. invicta had been eradicated (Hwang, 2009).

An eradication program of Wasmannia auropuncatata at the Marchena Island in the Galapagos Archipelago employing Amdro ${ }^{\circledR}$ (hydramethylnon) manually up to three times in the area at three month intervals between March and October 2001, was realized; the consequent surveys revealed the absence of $W$. auropunctata in May 2003 and April 2004, assuming a successful eradication (Causton et al. 2009).

Finally, a small infestation of Wasmannia auropunctata was discovered on the island of Maui, Hawaii; for an eradication purpose, during a year on twelve occasions, granular baits and a paste bait containing indoxacarb $(0.18 \%$ a.i.) were used. One year after initiation of treatments, no new detections have been made, suggesting the eradication of the little fire ant from Maui (Vanderwoude et al. 2010).

Apparently, no other documented efficacious eradication program of the four tramp ants has been reported, but should be in mind as soon as new invasions of these or other invasive ants are reported.
Conflicts of interest: The manuscript was prepared and revised by the author, who declares the absence of any conflict which can put the validity of the presented information in risk.

\section{REFERENCES}

1. ACHURY, R.; CHACÓN DE ULLOA, P.; ARCILA, Á.M. 2008. Composición de hormigas e interacciones competitivas con Wasmannia auropunctata en fragmentos de Bosque seco Tropical. Rev. Col. Entomol. 34(2):209-215.

2. ALDANA, R.C.; BAENA, M.S.; CHACÓN DE ULLOA, P. 1995. Introducción de la hormiga loca (Paratrechina fulva) a la reserva natural Laguna de Sonso (Valle del Cauca, Colombia). Bol. Mus. Ent. Univ. Valle. (Colombia). 3(1):1528.

3. ARMBRECHT, I.; JIMENEZ, E.; ALVAREZ, G.; ULLOACHACÓN, P.; ARMBRECHT, H. 2001. An ant mosaic in the Colombian rain forest of Choco (Hymenoptera: Formicidae). Sociobiology. (United States). 37:491-509.

4. ASCUNCE, M.S.; YANG, CH.-CH.; OAKEY, J.; CALCATERRA, L.; WU, W.-J.; SHIH, CH.-J.; GOUDET, J.; ROSS, K.G.; SHOEMAKER, D. 2011. Global invasion history of the Fire Ant Solenopsis invicta. Science. 331(6020):1066-1068. https://doi.org/10.1126/science.1198734

5. BEXTINE, B.R.; THORVILSON, H.G. 2002. Field applications of bait-formulated Beauveria bassiana alginate pellets for biological control of the Red Imported Fire Ant (Hymenoptera: Formicidae). Environmental Entomology. (United States). 31(4):746-752. https://doi. org/10.1603/0046-225X-31.4.746

6. BRANDÃO, C.R.F.; PAIVA, R.V.S. 1994. The Galapagos ant fauna and the attributes of colonizing ant species. In: Williams, D.E. (ed.). Exotic Ants Biology, Impact, and Control of Introduced Species. Westview Studies in Insect Biology. Westview Press. p.1-10.

7. BRIGHTWELL, R.J.; LABADIE, P.E.; SILVERMAN, J. 2010. Northward expansion of the invasive Linepithema bumile (Hymenoptera: Formicidae) in the Eastern United States is constrained by winter soil temperatures. Environmental Entomology. 39(5):1659-1665. https://doi.org/10.1603/ EN09345

8. BUREN, W. F. 1972. Revisionary studies on the taxonomy of the imported fire ants. The Journal of the Georgia Entomological Society. 7(1):1-26.

9. CALLCOTT, A.-M. A.; COLLINS, H.L. 1996. Invasion and range expansion of imported fire ants (Hymenoptera: Formicidae) in North America. Florida Entomol. 79:240251. 
10. CAMPOS-FARINHA, A.E. DE C.; ZORZENON, F.J. 2005. Predatory and interaction behaviors of Paratrechina fulva (Mayr) (Hymenoptera: Formicidae) on phytophagous insects on palm trees. Arq. Inst. Biol., São Paulo. 71:143144.

11. CASTAÑO-MENESES, G. 2012. First records of ants (Hymenoptera: Formicidae) from white mangrove (Laguncaria racemosa) soils in Xcalak, Quintana Roo, México. Dugesiana. (México). 19:11-116.

12. CAUSTON, C.E.; SEVILLA, C.R.; PORTER, S. 2009. Eradication of the little fire ant, Wasmannia auropunctata (Hymenoptera: Formicidae), from Marchena Island, Galapagos: On the edge of success? Florida Entomologist. 88:159-168. https://doi.org/10.1653/0015-4040(2005)088[0159:EO TLFA]2.0.CO;2

13. CLARK, D.B.; GUAYASAMIN, C.; PAZAMINO, O.; DONOSO, C.; PAEZ DE VILLACIS, Y. 1982. The tramp ant Wasmannia auropunctata: autecology and effects on ant diversity and distribution on Santa Cruz Island, Galapagos. Biotropica. 14:196-207.

14. CLARK, J. 1941. Notes on the Argentine ant and other exotic ants introduced into Australia. Memoirs of the National Museum of Victoria. 12:59-70.

15. COOK, J.L.; SPENCER, J.; ROGER, S.; GOLD, E.; VINSON, B. 1997. Distribution of Caenocholax fenyesi (Strepsiptera: Myrmecolacidae) and the habitats most likely to contain its stylopized host, Solenopsis invicta (Hymenoptera: Formicidae). Environmental Entomology. 26(5):1258-1262.

16. DAVIS, L.R.D.; VANDERMEER, R.K.; PORTER, S.D. 2001. Red imported fire ants expand their range across the West Indies. Florida Entomologist. 84(4):735-736.

17. DELABIE, J.H.C.; DA ENCARNAÇÃO, A.M.V.; CAZORLA, I.M. 1994. Relations between the little fire ant, Wasmannia auropunctata, and its associated mealybug, Planococcus citri, in Brazilian cocoa farms. In: Williams, D.E. (ed.). Exotic Ants Biology, Impact, and Control of Introduced Species. Westview Studies in Insect Biology. Westview Press. p.91103.

18. DE LA VEGA, I. 1994. Food searching behavior and competition between Wasmannia auropunctata and native ants on Santa Cruzand Isabela, Galapagos Islands. In: Williams, D.E. (ed.). Exotic Ants Biology, Impact, and Control of Introduced Species. Westview Studies in Insect Biology. Westview Press. p.74-79.

19. ERICKSON, J.M. 1971. The displacement of native ant species by the introduced Argentine Ant Iridomyrmex bumilis Mayr.
Psyche. (United States). 78(4):257-266. https://doi. org/10.1155/1971/34713

20. FONTENLA RIZO, J.L.; MATIENZO BRITO, Y. 2011. Hormigas invasoras y vagabundas de Cuba. Fitosanidad (Cuba). 15(4):253-259.

21. FONTENLA, J.L.; VÁZQUEZ, L.L.; HERNÁNDEZ, L.R. 1995. Un comentario sobre las hormigas locas (Paratrechina) cubanas, con énfasis en P. fulva. Cocuyo. (Cuba). 2: 6-7.

22. FOREL, A. 1911. Aperçu sur la distribution géographique et la phylogénie des fourmis. Memoires Ier Congres International d'Entomologie, Bruxelles, Aout,1010. 2:81100. Contributed by Smithsonian Libraries.

23. FOUCAUD, J.; ORIVEL, J.; LOISEAU, A.; DELABIE, J.H.C.; JOURDAN, H.; KONGHOULEUX, D.; VONSHAK, M.; TINDO, M.; MERCIER, J.; FRESNEAU, D.; MIKISSA, J, MCGLYNN, T.; MIKHEYEV, A.S.; OETTLER, J.; ESTOUP, A. 2010. Worldwide invasion by the little fire ant: routes of introduction and eco-evolutionary pathways. Evolutionary Applications. (United Kigdom). 3:363-374. https://doi.org/10.1111/j.1752-4571.2010.00119.x

24. GLOBALVOICES ORG. 2017. Japan Reacts with Alarm to Venomous Fire Ant Invasion. Disponible desde Internet en: https://globalvoices.org/2017/08/03/japan-reactswith-alarm-to-venomous-fire-ant-invasion/ (con acceso 23/04/2019).

25. GÓMEZ, C.; ROURA-PASCUAL, N.; BIRKEMOE, T. 2005. Argentine ants infesting Norwegian flats. Norw. J. Entomol. (Norway). 52:65-66.

26. GREEN, O.R. 1990. Entomologist sets new record at Mt Smart for Iridomyrmex humilis established in New Zealand. The Weta. (New Zealand). 13:14-16.

27. HARRIS, R.J.; BARKER, G. 2007. Relative risk of invasive ants (Hymenoptera: Formicidae) establishing in New Zealand. New Zealand J. Zoology. (United Kingdom). 34:161-178. https://doi.org/10.1080/03014220709510075

28. HÖLLDOBER, B.; WILSON, E.O. 1990. The ants. The Belknap Press of Harvard University Press, Cambridge, Massachusetts, 732p.

29. HWANG, J.S. 2009. Eradication of Solenopsis invicta by pyriproxyfen at the Shihmen Reservoir in northern Taiwan. Insect Science. (United Kingdom). 16(6):493-501. https:/ / doi.org/10.1111/j.1744-7917.2009.01279.x

30. JEMAL, A.; HUGH-JONES, M. 1993. A review of the red imported fire ant (Solenopsis invicta Buren) and its impacts 
on plant, animal, and human health. Preventive Veterinary Medicine. (Netherlands). 17:19-32.

31. JUCKER, C.; RIGATO, F.; REGALIN, R. 2008. Exotic ant records from Italy (Hymenoptera, Formicidae). Bollettino di Zoologia agraria e di Bachicoltura. (Italy). 40:99-107.

32. KEGEL, B. 2001. Die Ameise als Tramp. Von bilogischen Invasionen. Wilhelm Heyne Verlag, München. 448p.

33. KRAUSS, N.L.H. 1966. Biological control investigations on some Hawaiian weeds. Proc. Hawaiian Ent. Soc. 19:223231.

34. KUSNEKOV, N. 1951. El género Wasmannia en la Argentina (Hymeoptera: Formcidae). Acta Zoologica Lilloana. (Argentina). 10:173-182.

35. LEBRUN, E.G.; ABBOT'T, J.; GILBERT, L.E. 2013. Imported crazy ant displaces imported fire ant, reduces and homogenizes grassland ant and arthropod assemblages. Biological Invasions. 15(11):2429-2442. https://doi. org/10.1007/s10530-013-0463-6

36. LOFGREN, C.S. 1986. History of imported fire ants in the United States.In: Lofgren, C.S.; Vander Meer, R.K. [eds.]. Fire ants and leaf-cutting Ants. Westview Press, Boulder, CO. 435p.

37. LONGINO, J.T.; FERNÁNDEZ, F. 2007. Taxonomic review of the genus Wasmannia. In: Snelling, R.R.; Fisher, B.L.; Ward, P.S. (eds). Advances in Ant Systematics (Hymenotera: Formicidae): Homage to E.O. Wilson - 50 years of Contributions. Memoirs of the American Entomological Institute.

38. LUBIN, Y.D. 1984. Changes in the native fauna of the Galapagos Islands following invasion by the little red fire ant Wasmannia auropunctata. Biological J. of the Linnean Soc. (United Kingdom). 21(1-2):229-242. https://doi. org/10.1111/j.1095-8312.1984.tb02064.x

39. MARICONI, F.A.M. 1970. As saúvas. Editora Agronômica Ceres. São Paulo. 167p.

40. MOLONEY, S.; VANDERWOUDE, C. 2002. Red Imported Fire Ants: A threat to eastern Australia's wildlife? Management \& Restoration (Australia). 3(3):167-175. https://doi. org/10.1046/j.1442-8903.2002.t01-1-00109.x

41. NATIONAL PEST \& DISEASE OUTBRAKES. 2018. Red imported fire ants. Current situation. Disponible desde Internet en: https://www.outbreak.gov.au/currentresponses-to-outbreaks/red-imported-fire-ants (con acceso 03/01/2019).
42. PASSERA, L. 1994. Characteristics of Tramp Species. In: Williams, D.F. (ed). Exotic Ants Biology, Impact, and Control of Introduced Species. Westview Studies in Insect Biology. Westview Press. p.23-43.

43. PORTER, S.D.; NOGUEIRA DE SA, L.A.; MORRISON L.W. 2003. Establishment and dispersal of the fire ant decapitating fly Psendacteon tricuspis in North Florida. Biol. Control. (United States). 29:179-188.

44. PORTER, S.; SAVIGNANO, D.A. 1990. Invasion of polygyne fire ants decimates native ants and disrupts arthropod community. Ecology. 71(6):2095-2106. https://doi. org $/ 10.2307 / 1938623$

45. PUCKE'TT, R.T.; HARRIS, M.K. 2010. Pseudacteon spp. (Diptera: Phoridae), affect forager size ratios of Red Imported Fire Ants Solenopsis invicta (Hymenoptera: Formicidae) in Texas. Environmental Entomology. 39(5):1593-1600. https://doi. org/10.1603/EN09189

46. ROCHA FLORES, R.G.; GARCÍA MARTÍNEZ, O.; SÁNCHEZ PEÑA, S.R.; VILLARREAL QUINTANILLA, J.A. 2018. La hormiga argentina Linepithema humile: primer registro en Opuntia spp. Para el estado de San Luis Potosí, México. Southwestern Entomologist (United States). 43(3):781-785. https://doi.org/10.3958/059.043.0323

47. ROURA-PASCUAL, N.; SUAREZ, A.V.; GÓMEZ, C.; PONS, P.; TOUYAMA, Y.; WILD, A.L.; TOWSEND PETERSON, A. 2004. Geographic potential of Argentine ants (Linepithema bumile Mayr) in the face of global climate change. Proc. Roy. Soc. London. B Bio. (United Kingdom). 271(1557):25272535. https://doi.org/10.1098/rspb.2004.2898

48. SALGUERO R., B.; ARMBRECHT, I.; HURTADO T., T.; ARCILA C., A.M. 2011. Wasmannia auropunctata (Hymenoptera: Formicidae): ¿unicolonial o multicolonial? en el valle geográfico del río Cauca. Rev. Col. Entomología. (Colombia). 37(2):279-288.

49. SÁNCHEZ-PEÑA, S.R.; CHACÓN-CARDOSA, M.C.; RESÉNDEZ-PÉREZ, D. 2009. Identification of Fire Ants (Hymenoptera: Formicidae) from Northeastern Mexico with Morphology and Molecular Markers. Florida Entomologist. 92(1):107-115.

50. SANDERS, N.J.; GOTELLI, N.J.; HELLER, N.E.; GORDON, D.M. 2003. Community disassembly by an invasive species. Proc. Natl. Acad. Sci. U S A. 100(5):2474-2477. https:// doi.org/10.1073/pnas.0437913100

51. SOARES-BRANDÃO, J.S. 1941. A formiga cuiabana "versus" saúva. Sítios e Fazendas (Brasil). 6:36-38. 
52. SUAREZ, A.V.; HOLWAY, D.A.; CASE, T.J. 2001. Patterns of spread in biological invasions dominated by long distance jump dispersal: insights from Argentine ants. Proc. National Academy of Sciences of the United States of America. 98:1095-1100. https://doi.org/10.1073/pnas.98.3.1095

53. TENNANT, L.A. 1994. The ecology of Wasmannia auropunctata in primary tropical rainforest in Costa Rica and Panama. In: Williams, D.E. (ed). Exotic Ants Biology, Impact, and Control of Introduced Species. Westview Studies in Insect Biology. Westview Press. p.80-90.

54. TITUS, E.S.G. 1905: Report on the "New Orleans" ant (Iridomyrmex humilis Mayr). U.S. Bureau of Entomology Bulletin. 52:79-84.

55. TRAGER, J.C. 1984. A revision of the genus Paratrechina (Hymenoptera: Formicidae) of the continental United States. Sociobiology. (United States). 9(2):49-162.

56. ULLOA-CHACÓN, P.; CHERIX, D. 1990. The little fire ant Wasmannia auropunctata (R.) (Hymenoptera: Formicidae). In: Vander Meer, R.K.; Jaffe, K.; Cedeno, A. (Eds). Applied Myrmecology. A World Perspective. Westview Studies in Insect Biology. Westview Press. p.281-289.

57. USDA APHIS. GOV. 2018. Imported Fire Ants. Disponible desde Internet en: https://www.aphis.usda.gov/aphis/ ourfocus/planthealth/plant-pest-and-disease-programs/ pests-and-diseases/imported-fire-ants/ct_imported_fire_ ants (con acceso 01/12/2018).

58. VALLES, S.M.; WETTERER, J.K.; PORTER, S.D. 2015. The red imported fire ant (Hymenoptera: Formicidae) in the West Indies: distribution of natural enemies and a possible test bed for release of self-sustaining biocontrol agents. Florida Entomologist. 98(4):1101-1105. https:// doi.org/10.1653/024.098.0414

59. VANDER MEER, R.K.; JAFFE, K.; CEDENO, A. 1990. Applied Myrmecology. A World Perspective. Westview Studies in Insect Biology. Westview Press. 741p.

60. VANDERWOUDE, C.; ONUMA, K; REIMER, N. 2010. Eradicating Wasmannia auropunctata (Hymenoptera: Formicidae) from Maui, Hawaii: The use of combination treatments to control an arboreal invasive ant. Proc. Hawaiian Ent. Soc. 42:23-31.

61. VAN SCHLAGEN, J.J.; DAVIS, P.R.; WIDMER, M.A. 1994. Ant pests of western Australia, with particular reference to the argentine ant (Linepithema humile). In: Williams, D.E. (ed). Exotic Ants Biology, Impact, and Control of Introduced Species. Westview Studies in Insect Biology. Westview Press. p.174-180.
62. VAN WILGENBURG, E.; TORRES, W.C.; TSUTSUI, N.D. 2010. The global expansion of a single ant supercolony. Evolutionary Applications. (United Kingdom). 3(2):136 143. https://doi.org/10.1111/j.1752-4571.2009.00114.x

63. VONSHAK, M.; DAYAN, T.; IONESCU-HIRSH, A.; FREIDBERG, A.; HEFETZ, A. 2010. The little fire ant Wasmannia auropunctata: a new invasive species in the Middle East and its impact on the local arthropod fauna. Biological Invasions. (Netherlands). 12(6):1825-1837. https://doi. org/10.1007/s10530-009-9593-2

64. WALSH, P.D.; HENSCHEL, P.; ABERNETHY, K.A.; TUTIN, C.E.G.; TELFER, P.; LAHM, S.A. 2004. Logging speeds little red fire ant invasion of Africa. Biotropica. (United States). 36(4):637-641. https://doi.org/10.1111/j.1744-7429.2004. tb00358.x

65. WANG, L.; LU, Y.; XU, Y.; ZENG, L. 2012. The current status of research on Solenopsis invicta Buren (Hymenoptera: Formicidae) in Mainland China. Asian Myrmecology. (Malaysia). 5(1):125-138.

66. WARD, D.F.; GREEN, C.; HARRIS, R.J.; HARTLEY, S.; LESTER, P.J.; STANLEY, M.C.; SUCKLING, D.M.; TOFT, R.J. 2010. Twenty years of Argentine ants in New Zealand: past research and future priorities for applied management. New Zealand Entomologist. (United Kingdom). 33:68-78. https://doi.org/10.1080/00779962.2010.9722193

67. WARD, D. 2009. The potential distribution of the red imported fire ant, Solenopsis invicta Buren (Hymenoptera: Formicidae), in New Zealand. New Zealand Entomologist. 32:67-75.

68. WARD, D.F.; HARRIS, R.; STANLEY, M.C. 2005. Human mediated range expansion of Argentine ants in New Zealand. Sociobiology. (United States). 45:401-408.

69. WARD, P.S. 1987. Distribution of the introduced Argentine Ant (Iridomyrmex bumilis) in natural habitats of the lower Sacramento Valley and its effect on the indigenous ant fauna. Hilgardia. (United States). 55(2):1-16.

70. WETTERER, J.K.; WILD, A.L.; SUAREZ, A.V.; ROURAPASCUAL, N.; ESPADALER, X. 2009. Worldwide spread of the Argentine ant, Linepithema bumile (Hymenoptera: Formicidae). Myrmecol. News. (Austria). 12:187-194.

71. WETTERER, J.K. 2013. Worldwide spread of the little fire ant, Wasmannia auropunctata (Hymenoptera: Formicidae). Terrestrial Arthropod Reviews. (Netherland). 6(2013):173184 
72. WETTERER, J.K.; SNELLING, R.R. 2006. The red imported fire ant, Solenopsis invicta, in the Virgin Islands (Hymenoptera: Formicidae). Florida Entomolologist. 89:431-434.

73. WETTERER, J.K.; DAVIS, L.R. 2010. Solenopsis invicta (Hymenoptera: Formicidae) in the Lesser Antilles. Florida Entomologist. 93(1):128-129. https://doi. org/10.1653/024.093.0120

74. WETTERER, J.K.; PORTER, S.D. 2003. The little fire ant, Wasmannia auropunctata: distribution, impact, and control. Sociobiology. (United States). 42:1-41.

75. WETTERER, J.K.; DAVIS, O.; WILLIAMSON, J. 2014. Boom and bust of the tawny crazy ant, Nylanderia fulva (Hymenoptera: Formicidae), on St. Croix, US Virgin Islands. Florida Entomologist. 97(3):1099-1103.

76. WILD, A.L. 2004. Taxonomy and distribution of the Argentine Ant, Linepithema humile (Hymenoptera: Formicidae). Ann. Entomol. Soc. Am. (United States). 97(6):1204-1215.

77. WILLIAMS, D.E. 1994. Exotic Ants Biology, Impact, and Control of Introduced Species. Westview Studies in Insect Biology. Westview Press. 332p.

78. WILLIAMS, R.N.; DE MENEZES, M.; ALLEN, G.E.; BUREN, W.F.; WHITCOMB, W.H. 1975. Observacões ecológicas a formiga lava-pé, Solenopsis invicta Bure, 1972 (Hymenopter: Formicidae). Revista de Agricultura, Piracicaba. (Brazil). 50:9-22.

79. WYLIE, F.R.; JANSSEN-MAY, S. 2016. Red imported fire ant in Australia: what if we lose the war? Ecological Management \& Restoration. (United Kingdom). 18:32-44. https://doi. org/10.1111/emr.12238

80. ZHANG, X.; HOU Y.-M. 2013. Invasion history of Solenopsis invicta (Hymenoptera: Formicidae) in Fujian, China based on mitochondrial DNA and its implications in development of a control strategy. Insect Science. (United Kingdom). 21(4):493-498. https://doi.org/10.1111/1744-7917.12042

81. ZHANG, Y.; MA, J.H.; JIN, G.Y.; HUANG, J.P. 2007. Definition and management on key area of Solenopsis invicta control in port. Plant Quarantine. (China). 12:56-57.
82. ZHOU, A.; LU, Y.; ZENG, L.; XU, Y.; LIANG, G. 2013. Solenopsis invicta (Hymenoptera: Formicidae), defend Phenacoccus solenopsis (Hemiptera: Pseudococcidae) against its natural enemies. Environmental Entomology. (United States) 42(2):247-252. https://doi.org/10.1603/EN12168

83. ZENG, L.; LU, Y.Y.; HE, X.F.; ZHANG, W.Q.; LIANG, G.W. 2005. Identification of red imported fire ant Solenopsis invicta to invade mainland China and infestation in Wuchuan, Guangdong. Chinese Bulletin of Entomology. (China). 42(2):144-148.

84. ZENNER DE POLANÍA, I.; RUIZ BOLAÑOS, N. 1985. Hábitos alimenticios y relaciones simbióticas de la "hormiga loca" Nylandería fulva con otros artrópodos. Rev. Col. Entomología 11:3-10.

85. ZENNER-POLANIA, I. 1990a. Biological aspects of the "Hormiga Loca," Paratrechina (Nylanderia) fulva (Mayr), in Colombia. In: Vander Meer, R.K.; Jaffe, K.; Cedeno, A. (Eds.). Applied Myrmecology. A World Perspective. Westview Studies in Insect Biology. Westview Press. p.290297.

86. ZENNER POLANÍA, I. 1990b. Management of the "Hormiga Loca" Paratrechina (Nylanderia) fulva (Mayr), in Colombia. In: Vander Meer, R.K.; Jaffe, K.; Cedeno, A.(Eds.). Applied Myrmecology. A World Perspective. Westview Studies in Insect Biology. Westview Press. p.701-707.

87. ZENNER-POLANIA, I. 1994. Impact of Paratrechina fulva on other ant species. In: William, D.F. (Ed.). Exotic ants. Biology, impact, and control of introduced species. Westview Studies in Insect Biology. Westview Press. p.121132.

88. ZENNER DE POLANÍA, I.; GARCÍA M., C.G.; SÁNCHEZ O., E. 2001. Alternativa para el manejo del complejo de la escama Pulvinaria pos. elongata Newstead y la hormiga Paratrechina fulva (Mayr) en caña panelera. Rev. U.D.C.A Act. \& Div. Cient. (Colombia). 4(1):56-63. 